\title{
Strong El Niño-Southern Oscillation events and the economics of the international rice market
}

\author{
Chi-Chung Chen ${ }^{1, *}$, Bruce A. McCarl ${ }^{2}$, Ching-Cheng Chang ${ }^{3}$ \\ ${ }^{1}$ Department of Applied Economics, National Chung-Hsing University, Taichung 402, Taiwan \\ ${ }^{2}$ Department of Agricultural Economics, Texas A\&M University, College Station 77843, Texas, USA \\ ${ }^{3}$ Institute of Economics, Academia Sinica and Department of Agricultural Economics, National Taiwan University, \\ Taipei 115, Taiwan
}

\begin{abstract}
EL Niño-Southern Oscillation (ENSO) events are costly to agriculture in that they contribute to its variability. It is possible that climate change will increase ENSO event frequency and severity. This study investigates the economic consequences of ENSO events for the international rice market, along with the consequences of a possible increase in event severity. Historical data are used to estimate the ENSO impact on rice production, and the resulting parameters are incorporated into a stochastic spatial equilibrium model. Our results indicate that an average El Niño or La Niña event reduces annual welfare in the world rice market by US\$741 million or US\$2058 million, respectively. The additional welfare loss amounts to US\$595 million or US\$637 million, respectively, if extreme El Niño or La Niña events take place, and to US\$1337 million or US\$1392 million, respectively, if the frequencies of extreme events increase. The empirical results also show that an expansion in both trade and storage capacity can mitigate ENSO damage.
\end{abstract}

KEY WORDS: El Niño $\cdot$ La Niña $\cdot$ Extreme weather $\cdot$ Stochastic model $\cdot$ Rice $\cdot$ International trade Resale or republication not permitted without written consent of the publisher

\section{INTRODUCTION}

The El Niño-Southern Oscillation (ENSO) is a pervasive climate phenomenon associated with regional variations in climate throughout the world. ENSO is comprised of 3 phases, a warm (El Niño), a cold (La Niña), and a neutral phase. The economic impacts of the ENSO phases have been widely discussed in recent years. Many studies have estimated the effects of ENSO on crop yields, water resources, and agricultural income or sectoral performance (e.g. Adams et al. 1995, Mjelde et al. 1997, Solow et al. 1998, Centeno et al. 2000, Chen \& McCarl 2000, Chen et al. 2001, 2002). Some of these studies have examined the implications of ENSO for rice production. Centeno et al. (2000) estimated the effect of ENSO on Asian rice yields using a crop growth model, while Chen \& McCarl (2000) applied an econometric approach to estimate the effect of ENSO on rice production in a number of regions of the world.

However, the results generated by such studies typically represent the effects of average ENSO events.
Timmermann et al. (1999) found that global climate change may have altered the ENSO characteristics, with more frequent and extreme episodes. Trenberth \& Hoar $(1996,1997)$ found the frequency of El Niño to increase and the frequency of La Niña to decrease over the period of 1976 to 1995. In this study, we estimate the effects of both average and strong ENSO episodes on the international rice market.

According to the estimates of Timmermann et al. (1999), the probabilities for the ENSO warm, cool and neutral phases to occur are $0.238,0.250$ and 0.512 , respectively. They project that the probabilities of these 3 ENSO phases will change under the increasing levels of greenhouse gases assumed in the IPCC scenario IS92 projections. To reflect these projections, the average and strong ENSO event impacts on rice production for major rice-producing nations are estimated using an econometric approach involving time series data. Subsequently, a stochastic world rice model that incorporates production, consumption, trade, and storage activities is employed to simulate the effects of 
average and strong ENSO events on the world rice market. The frequency and severity of ENSO events are adjusted to reflect the global climate change effects. Finally, the possible adaptation strategies of trade and storage are examined, along with policy implications and recommendations.

\section{ENSO EFFECTS ON RICE PRODUCTION}

Rice is the most important staple food crop in the Asia-Pacific region. Of 25 major rice-producing nations, 17 are located in this region, which together produce $92 \%$ and consume $90 \%$ of the world's total rice production. Throughout the region, much of the present interannual variability in precipitation is linked to the ENSO phenomenon (Matthews et al. 1995).

Centeno et al. (2000) found that high levels of radiation during an El Niño event promotes high levels of yields through increased photosynthesis under irrigated rice farming, but very high temperatures, such as those $>35^{\circ} \mathrm{C}$, may give rise to spikelet sterility and, consequently, low yields (Centeno et al. 2000). Therefore, the clear skies and droughts during extreme El Niño events are expected to bring negative effects on rice production. In India, ENSO was found responsible for rice yield variability and caused rice production to drop by $7 \%$ during an El Niño event and to increase by $3 \%$ during a La Niña event (Selvaraju 2003). However, in Sri Lanka, the rainfall in the El Niño years of 1957/1958, 1965/1966, and 1972/1973 was so high that floods were reported in some areas and rice production dropped (Zubair 2002). Because most of the world's rice production fields are flooded as an ENSO event occurs, large variations in yield due to water stress or radiation changes are unlikely during an average ENSO event, but large fluctuations in both yield and planting area would be possible if a strong event occurs.
Although the classification of the ENSO phase is known with certainty, the strength of ENSO phase is uncertain. Therefore, the approach of Song \& Carter (1996) is adopted to capture the unknown impact of ENSO on rice production. Non-climate-related factors are used as explanatory variables, with the residuals representing unknown ENSO effects. Eq. (1) models total rice production as being influenced by planting acreage and technology as follows:

$$
Y_{i}=\alpha+\beta_{1} \mathrm{AR}_{i}+\beta_{2} \mathrm{AR}_{i}^{2}+\beta_{3} \text { Year }+\varepsilon_{i}
$$

where the subscript $i$ represents production regions, $Y$ is the annual rice production, AR is the planting acreage, Year is a time trend representing technological advances over time, $\varepsilon$ is the error term, and $\alpha$, $\beta_{1}, \beta_{2}$, and $\beta_{3}$ are parameters to be estimated. The planting acreage is used as a composite management variable, including the influence of government policies.

In Eq. (1), the residuals measure the deviations from the average production. A positive residual signals the presence of an above-average observation and vice versa. The residuals are grouped by the ENSO phases to reflect the impact of ENSO on rice production. Such an approach also allows us to quantitatively identify the deviation effects of an individual ENSO event (such as the 1982/1983 or 1997/1998 El Niño) from normal production.

Rice can be separated into 2 varieties, Japonica and Indica, on the basis of taste and consumption preferences. We selected the Indica variety as our study target because the global production, consumption, and amount traded of this type of rice are all higher than in the case of the Japonica variety. There are 23 Indica rice production regions defined in Table 1. The data cover the period from 1961 to 1998 and are drawn from the Food and Agriculture Organization (FAO) (faostat. fao.org/default.aspx).

Table 1. Definitions of regions

\begin{tabular}{|llll|}
\hline Region & Country & Region & Country \\
\hline Importers & & Exporters & China \\
Bangladesh & Bangladesh & China (1998) & Taiwan \\
China (1995) & China & Taiwan & India \\
Indonesia & Indonesia & India & Myanmar \\
DPR Korea & DPR Korea & Myanmar & Pakistan \\
Philippines & Philippines & Pakistan & Thailand \\
Other Asian & Afghanistan, Cambodia, Iran, Iraq, Lao PDR, & Thailand & Vietnam \\
& Malaysia, Nepal, Sri Lanka, Turkey, other Asian & Vietnam & USA \\
Central America & Costa Rica, Cuba, Dominica, Mexico, Panama & USA & Argentina, Colombia, \\
Europe & Italy, Portugal, Spain, other Europe & South America \\
Former USSR & Former USSR & & Ecuador, Guyana, \\
Brazil & Brazil & & Peru, Surinam, Uruguay, \\
Africa & African countries & & Venezuela \\
Rest of world & & Australia & Australia \\
\hline
\end{tabular}


The estimation results from Eq. (1) are shown in Table 2. Most of the estimated parameters are found to be statistically significant. The high R-square values and the Theil coefficients being close to zero indicate that these equations perform well statistically and pass the fitness test.

The individual ENSO effects derived from the residuals are shown in Table 3. The results indicate that the La Niña phase gives rise to a poorer harvest than the neutral or El Niño phases. In particular, rice production in Myanmar, the Philippines, North Korea, Central America, and Brazil is reduced by at least $5 \%$ during the La Niña phase. However, the El Niño phase is linked with higher yields in a number of major Indica rice producing countries such as India, Pakistan, and Thailand. Only a few countries, such as the Philippines and Indonesia, experience negative effects from the El Niño (warm) phase, but these negative effects are less dramatic than in the La Niña (cold) phase. Note also that the residuals are mostly positive during the neutral years. One possible explanation is that the lower harvests in ENSO years stimulate rice producers to respond with higher production in normal years.

Table 2. Estimation of production by trading regions. AR: planting acreage. ${ }^{*}$ Significant at $10 \%$ level, ${ }^{* *}$ significant at $5 \%$ level

\begin{tabular}{|c|c|c|c|c|c|c|c|c|}
\hline \multirow[t]{2}{*}{ Region } & \multirow{2}{*}{\multicolumn{4}{|c|}{$\begin{array}{c}\text {-Estimated parameters } \\
\qquad \beta_{2} \mathrm{AR}^{2}\end{array}$}} & & & \multirow{2}{*}{$\begin{array}{l}\text { Adjusted } \\
\text { R-square }\end{array}$} & \multirow{2}{*}{$\begin{array}{l}\text { Theil- } \\
\text { coefficient }\end{array}$} \\
\hline & & & & & $\begin{array}{c}\beta_{3} \mathrm{Ye} \\
\text { Mean }\end{array}$ & $\mathrm{SD}$ & & \\
\hline Bangladesh & $-19.88^{*}$ & 12.76 & 0.001 & 0.0006 & $419.7^{*}$ & 25.5 & 0.93 & 0.039 \\
\hline China & $40.73^{* *}$ & 10.8 & $-0.0006^{* *}$ & 0.0001 & $3378.6^{* *}$ & 117.3 & 0.98 & 0.028 \\
\hline India & $-41.51^{* *}$ & 9.71 & $0.0005^{* *}$ & 0.0001 & $1161.4^{* *}$ & 246.4 & 0.96 & 0.040 \\
\hline Indonesia & 1.48 & 3.81 & 0.0001 & 0.0001 & $792.2^{* *}$ & 173.4 & 0.98 & 0.038 \\
\hline DPR Korea & $11.74^{* *}$ & 2.83 & $-0.004^{* *}$ & 0.0015 & -16.47 & 12.31 & 0.75 & 0.120 \\
\hline Myanmar & -13.00 & 10.63 & 0.0013 & 0.001 & $286.4^{* *}$ & 21.0 & 0.89 & 0.064 \\
\hline Pakistan & $3.81^{*}$ & 2.05 & -0.0001 & 0.0006 & 17.7 & 17.94 & 0.93 & 0.053 \\
\hline Philippines & 4.00 & 12.05 & -0.0003 & 0.0017 & $187.4^{* *}$ & 9.50 & 0.94 & 0.049 \\
\hline Thailand & -0.0002 & 0.0003 & 0 & 0.0000 & $338.0^{* *}$ & 23.70 & 0.91 & 0.045 \\
\hline Vietnam & $-23.76^{* *}$ & 5.19 & $0.002^{* *}$ & 0.0003 & $272.7^{* *}$ & 63.9 & 0.96 & 0.048 \\
\hline Other Asian & $-9.70^{* *}$ & 2.62 & $0.001^{* *}$ & 0.0002 & $164.0^{* *}$ & 8.21 & 0.97 & 0.025 \\
\hline USA & 0.21 & 2.42 & $0.002^{*}$ & 0.001 & $90.25^{* *}$ & 7.96 & 0.97 & 0.034 \\
\hline Central America & 7.70 & 5.75 & -0.003 & 0.004 & $31.6^{* *}$ & 2.91 & 0.87 & 0.065 \\
\hline Europe & $-32.02^{* *}$ & 12.40 & $0.046^{* *}$ & 0.016 & $21.30^{* *}$ & 2.92 & 0.85 & 0.047 \\
\hline Former USSR & $4.59^{* *}$ & 0.62 & 0.0004 & 0.0006 & $-21.04^{* *}$ & 2.36 & 0.98 & 0.039 \\
\hline Brazil & 1.37 & 1.31 & -0.0001 & 0.0001 & $117.6^{* *}$ & 12.42 & 0.77 & 0.066 \\
\hline South America & 1.07 & 1.01 & $0.001^{* *}$ & 0.0003 & $64.55^{* *}$ & 12.47 & 0.98 & 0.027 \\
\hline Africa & $-2.33^{* *}$ & 1.05 & $0.0003^{* *}$ & 0.0001 & $128.5^{* *}$ & 48.6 & 0.97 & 0.034 \\
\hline Europe & -1.97 & 1.37 & $0.033^{* *}$ & 0.007 & $17.94^{* *}$ & 2.38 & 0.96 & 0.064 \\
\hline
\end{tabular}

Table 3. The effects of ENSO on rice production (in metric tonnes). AvNiño: average El Niño; AvNiña: average La Niña

\begin{tabular}{|c|c|c|c|c|c|}
\hline & & \multirow{3}{*}{$\begin{array}{l}\text { Production } \\
(1000 \mathrm{t})\end{array}$} & \multicolumn{3}{|c|}{ Percentage change (\%) due to: } \\
\hline & & & \multicolumn{2}{|c|}{ Average ENSO } & \multirow{2}{*}{$\begin{array}{l}\text { Extreme event } \\
\text { 1997/1998 El Niño }\end{array}$} \\
\hline & & & AvNiño & AvNiña & \\
\hline \multirow[t]{9}{*}{ Exporters } & China & 104518 & -0.23 & -1.05 & -3.91 \\
\hline & India & 86381 & 0.23 & -1.71 & -8.57 \\
\hline & Myanmar & 10586 & -2.67 & -7.34 & -4.91 \\
\hline & Pakistan & 4697 & 1.32 & 2.37 & 7.20 \\
\hline & Thailand & 15037 & 1.83 & -2.73 & 4.24 \\
\hline & Vietnam & 18944 & -0.76 & 1.02 & -8.42 \\
\hline & USA & 4854 & -2.59 & 2.62 & -3.55 \\
\hline & South America & 5435 & 0.87 & 1.34 & 1.03 \\
\hline & Australia & 889 & -3.68 & -1.36 & -8.49 \\
\hline \multirow[t]{10}{*}{ Importers } & Bangladesh & 19904 & 1.44 & -1.49 & 7.30 \\
\hline & Indonesia & 33455 & -1.79 & -1.83 & -13.77 \\
\hline & Korea DRP & 1591 & -5.36 & -9.25 & -5.02 \\
\hline & Philippines & 5560 & -5.85 & -5.82 & -32.30 \\
\hline & Other Asian & 10351 & -1.65 & 2.31 & 1.83 \\
\hline & Central America & 1450 & -1.91 & -5.87 & -13.79 \\
\hline & Europe & 300 & -0.59 & -4.64 & 13.79 \\
\hline & Former USSR & 737 & 4.22 & -2.61 & 35.51 \\
\hline & Brazil & 5265 & 0.51 & -10.23 & -21.5 \\
\hline & Africa & 10493 & 1.83 & 2.15 & -3.24 \\
\hline \multicolumn{2}{|c|}{ Total production } & 340447 & 339532 & 335606 & 321418 \\
\hline
\end{tabular}


The effects of strong ENSO events on rice production can be estimated from Eq. (1). Based on classification by Redmond (2007), a strong El Niño event occurs when the Southern Oscillation Index (SOI) is less than -1 , while a strong La Niña event is found when the SOI is more than +1 . Therefore, the years 1965/1966, 1972/1973, 1977/1978, 1982/1983, and 1997/1998 are classified as strong El Niño events and the years 1973/1974, 1975/1976, and 1988/1989 are classified as strong La Niña events. The last column of Table 3 shows the effects of the strong El Niño in 1997/1998 on rice production. The results indicate that the effects are more intense than those of the average ENSO phases.
Table 4. Definitions of variables

\begin{tabular}{|c|c|c|}
\hline Variables & Definitions & Units \\
\hline$\rho(s)$ & Probability of ENSO state $s$ & $\%$ \\
\hline$t_{\mathrm{em}}$ & Transportation cost from exporter e to importer $m$ & $\mathrm{US} \$ \mathrm{t}^{-1}$ \\
\hline $\operatorname{tar}_{m}$ & Import tariff imposed by importer $m$ & US\$ \\
\hline $\operatorname{prs}_{i}$ & Domestic subsidy in trading region $i$ & US\$ \\
\hline $\operatorname{exs}_{e}$ & Export subsidy employed by exporter e & US\$ \\
\hline $\operatorname{stoc}_{i}$ & Storage cost in trading region $i$ & $\mathrm{US} \$ \mathrm{t}^{-1}$ \\
\hline $\mathrm{YENSO}_{\text {is }}$ & $\begin{array}{l}\text { ENSO impact on rice production in trading region } i \\
\text { under ENSO state } s\end{array}$ & $\mathrm{t}$ \\
\hline $\mathrm{QD}_{\text {is }}$ & $\begin{array}{l}\text { Domestic demand in trading region } i \text { under ENSO } \\
\text { state } s\end{array}$ & $\mathrm{t}$ \\
\hline $\mathrm{QS}_{i}$ & Domestic supply in trading region $i$ & $\mathrm{t}$ \\
\hline$f_{i}\left(\mathrm{QD}_{i s}\right)$ & Inverse demand function in trading region $i$ & - \\
\hline$g_{i}\left(\mathrm{QS}_{i}+\mathrm{YENSO}_{i s}\right)$ & Inverse supply function in trading region $i$ & - \\
\hline $\mathrm{TRE}_{\text {ems }}$ & Quantity traded between exporter $e$ and importer $m$ & $\mathrm{t}$ \\
\hline $\mathrm{STOA}_{i s}$ & $\begin{array}{l}\text { Addition to storage in trading region } i \text { under ENSO } \\
\text { state } s\end{array}$ & $\mathrm{t}$ \\
\hline $\mathrm{STOR}_{i s}$ & $\begin{array}{l}\text { Removal from storage in trading region } i \text { under ENSO } \\
\text { state } S\end{array}$ & $\mathrm{t}$ \\
\hline
\end{tabular}

$$
\begin{aligned}
& \sum_{m} \mathrm{TRE}_{e m s}-\left(\mathrm{QS}_{e}+\mathrm{YENSO}_{e s}\right) \\
& -\mathrm{STOR}_{e s}+\mathrm{QD}_{e s}+\mathrm{STOA}_{e s} \leq 0 \quad \forall e, s \\
& \sum_{s} \rho(\mathrm{s}) \times\left[\mathrm{STOA}_{i s}-\mathrm{STOR}_{i s}\right]=0 \quad \forall i
\end{aligned}
$$

Equation variables are defined in Table 4. The model in Eqs. (2) to (5) maximizes total expected surplus of the consumer and producer together (CSPS) subject to market equilibrium and stock clearance conditions in each region. The consumer surplus is a proxy for the welfare of consumers, while the producer surplus is a proxy for the welfare of producers. The first line in Eq. (2) is the probability-weighted area under the demand curve minus the area under the supply curve, while the second line is the transportation and storage costs. The third line represents government policy interventions in the rice market, including a domestic price subsidy (prs $\times$ QS), an import tariff $\left(\operatorname{tar}_{m} \times \sum \mathrm{TRE}_{e m s}\right)$ and an export subsidy ( $\operatorname{exs}_{e} \times \sum_{m} \mathrm{TRE}_{e m s}$ ).

Eqs. (3) \& (4) are the supply and demand balance constraints for importers and exporters under each ENSO state. Eq. (3) states that the total supply in each region, including imports (TRE), domestic supply (QS), and variations from ENSO (YENSO) should exceed total demand, which includes domestic demand (QD) and net storage additions (STOA - STOR). Eq. (5) is a longrun equilibrium constraint for storage activities, which ensures average storage withdrawals equal to average storage additions.

There are 2 important properties in this model. First, since production in each trading region is affected by the ENSO state, the residual estimates from Eq. (1) will be transported into Eqs. (3) \& (4) as $\mathrm{YENSO}_{i s}$. This

$$
\begin{aligned}
& \text { Max CSPS }= \\
& \sum_{s} \rho(s) \times\left\{\sum_{i}\left[\int f_{i}\left(\mathrm{QD}_{i s}\right) \mathrm{dQD}_{i s}-\int g_{i}\left(\mathrm{QS}_{i}+\mathrm{YENSO}_{i s}\right) \mathrm{dQS}_{i}\right]\right. \\
& -\sum_{e} \sum_{m} t_{e m} \times \mathrm{TRE}_{e m s}-\sum_{i} \mathrm{stoc}_{i} \times\left(\mathrm{STOA}_{i s}-\mathrm{STOR}_{i s}\right) \\
& \left.-\sum_{i} \mathrm{prs}_{i} \times \mathrm{QS}_{i}-\sum_{m} \operatorname{tar}_{m} \times \sum_{e} \mathrm{TRE}_{e m s}+\sum_{e} \mathrm{exs}_{e} \times \sum_{m} \mathrm{TRE}_{e m s}\right\} \\
& s t-\sum_{e} \mathrm{TRE}_{e m s}-\left(\mathrm{QS}_{m}+\mathrm{YENSO}_{m s}\right) \\
& \quad-\mathrm{STOR}_{i s}+\mathrm{QD}_{m s}+\mathrm{STOA}_{m s} \leq 0
\end{aligned}
$$


YENSO $_{\text {is }}$ term will shift the domestic supply curve, and, thus, domestic demand, trade, storage, and prices in each trading region are affected and become ENSOstate dependent.

Second, the trading prices are endogenously determined in the model. From the Kuhn-Tucker conditions (i.e. the necessary conditions for a solution in nonlinear programming to be optimal), we obtain:

$$
\mu-\lambda-t-\text { stoc }- \text { prs }- \text { tar }=0
$$

where $\mu$ and $\lambda$ are the ENSO-state dependent equilibrium prices of Eqs. (3) \& (4), respectively, which are interpreted as the import and export prices. Eq. (6) implies that transportation cost $(t)$, storage cost (stoc) and policy interventions (prs and tar) play a role in forming the price wedges between importing and exporting countries and determining the import volume in each country. If there is no policy intervention, i.e. prs $=\operatorname{tar}=0$, then Eq. (6) may be simplified as $\mu-\lambda-t=0$. Such a condition characterizes a perfectly competitive market as shown in Takayama \& Judge (1971).

This model is applied to the international rice market using 1998 data as the baseline. The model requires bilateral trade flows among all regions, as well as quantities and prices of supply and demand in each region. The main data source is the FAO (faostat.fao. org/default.aspx). All quantities are converted into milled rice. Demand and supply elasticities are obtained from Cramer et al. (1993). The storage cost is assumed to be the supply price multiplied by an assumed annual interest rate of $7 \%$. Trade data are obtained from the World Trade Database on CD-ROM complied by Statistics Canada (www.statcan.ca/menuen.htm). Finally, transportation cost and policy parameters, including import tariffs, export subsidies, and production subsidies are obtained from Chen \& McCarl (2000) and the Global Trade Analysis Project (GTAP) database (McDougall et al. 1998).

\section{MODEL CALIBRATION}

Model calibration is an important step of the model development process before it is ready for policy simulations. The 3 policy intervention parameters in the objective function are used as adjustment tools to allow the model solutions to be consistent with the observed data. For instance, if the modelled quantity consumed is higher but production is lower than the observed data in an importing country, the import tariff parameter is adjusted downward to reduce consumption but increase production simultaneously. When the model solutions for all trading countries are close to the observed data, the prices will also be very close to the observed data.

Behind this adjustment process is the theory of strategic trade policy. Assuming that the transportation and storage costs remain constant, any change in government intervention policies could change the deviations of the equilibrium prices between importing

Table 5. Comparisons between observed and model-generated supply/demand quantities and prices by region. Dev.: deviation

\begin{tabular}{|c|c|c|c|c|c|c|c|c|c|}
\hline \multirow[t]{2}{*}{ Regions } & \multicolumn{3}{|c|}{ Demand quantities (t) } & \multicolumn{3}{|c|}{ Supply quantities (t) } & \multicolumn{3}{|c|}{ Prices (US\$ t $t^{-1}$ ) } \\
\hline & Observed & Model & $\%$ Dev. & Observed & Model & $\%$ Dev. & Observed & Model & \% Dev. \\
\hline \multicolumn{10}{|l|}{ Importers } \\
\hline Indonesia & 42426871 & 44374690 & 4.59 & 33455894 & 31875444 & -4.72 & 313.97 & 318.39 & 1.41 \\
\hline DPR Korea & 1896330 & 1959169 & 3.31 & 1591830 & 1691767 & 6.28 & 133524.00 & 129307.00 & -3.16 \\
\hline Philippines & 8286056 & 8994094 & 8.54 & 5560100 & 5164405 & -7.12 & 445.55 & 432.52 & -2.92 \\
\hline Europe & 797034 & 786249 & -1.35 & 300737 & 274593 & -8.69 & 1316.86 & 1332.16 & 1.16 \\
\hline Former USSR & 1264828 & 1216647 & -3.81 & 737761 & 757937 & 2.73 & 218.94 & 234.25 & 6.99 \\
\hline Brazil & 5892084 & 5496900 & -6.71 & 5265692 & 5483850 & 4.14 & 359.64 & 370.66 & 3.06 \\
\hline Africa & 14450901 & 15403388 & 6.59 & 10493283 & 9568530 & -8.81 & 416.52 & 408.78 & -1.86 \\
\hline Rest of world & 105679 & 97737 & -7.51 & - & - & - & 416.52 & 424.31 & 1.87 \\
\hline \multicolumn{10}{|l|}{ Exporters } \\
\hline Thailand & 9245072 & 8944096 & -3.26 & 15037728 & 13861057 & -7.82 & 346.27 & 331.22 & -4.35 \\
\hline Vietnam & 14942875 & 14472738 & -3.15 & 18944575 & 19789302 & 4.46 & 1504.44 & 1461.80 & -2.83 \\
\hline USA & 1990552 & 2031067 & 2.04 & 4854809 & 4853177 & -0.03 & 662.90 & 622.57 & -6.08 \\
\hline South America & 4341989 & 4427590 & 1.97 & 5434986 & 5147488 & -5.29 & 361.86 & 343.90 & -4.96 \\
\hline Australia & 435556 & 446138 & 2.43 & 888873 & 813397 & -8.49 & 256.92 & 239.06 & -6.95 \\
\hline
\end{tabular}


and exporting countries and result in different solutions for production, consumption, and trade. Given that government policy is very difficult to measure, policy parameters were used to fine-tune calibration by matching the model solutions with the observed data for 1998. The comparisons between model solutions and observed data of demand/supply quantities and prices for each trading region are listed in Table 5. Because the percentage deviations are mostly $<8 \%$, the comparisons indicate that the model is verified and is suitable for depicting the international rice market.

\section{SCENARIO DESIGN}

Six scenarios simulate the economic impacts of strong and more frequent ENSO phenomena on the international rice market and the possible outcome of governmental mitigation efforts. They are as follows:

1. Base: This scenario ignores ENSO impacts. The model becomes deterministic with 1 ENSO-state across all years. The average production levels in each trading country are used in this simulation; they are displayed in the first column of Table 3.

2. AvNiño and AvNiña (average El Niño and La Niña): The model is simulated using the production from an average El Niño or an average La Niña event. The percentage changes in production based on the average of El Niño phase and the average of La Niña phase in each trading country are displayed in the fourth and fifth columns of Table 3. These percentages are also used to calculate $\mathrm{YENSO}_{\text {is }}$ for Eqs. (3) \& (4).

3. SNiño1 to SNiño5 and SNiña1 to SNiña3 (strong El Niño and La Niña, respectively): The model is designed to simulate the impact from extreme El Niño or extreme La Niña events. Based on the classification by Redmond (2007), scenarios SNiño1 to SNiño5 simulate the production changes that characterize 5 strong El Niño events in 1965/1966, 1972/1973, 1977/1978, 1982/1983, and 1997/1998, respectively. Scenarios SNiña1 to SNiña3 simulate the impacts from 3 strong La Niña episodes in the years 1973/1974, 1975/1976, and 1988/1989.

4. FNiño1 to FNiño5 and FNiña1 to FNiña3 (increase in frequency of strong and more frequent El Niño and La Niña events, respectively): These 2 scenarios simulate the impacts from changes in the magnitudes and frequencies of the El Niño and La Niña events. In the past 38 yr, El Niño and La Niña events occurred on 10 and 8 occasions, respectively. Therefore, we assume that the probabilities of these 2 ENSO phases are 0.263 (i.e. 10/38) and 0.210 (i.e. 8/38), respectively, in our baseline model. Timmermann et al. (1999) found that global warming has the potential to increase the fre- quencies of these 2 phases to 0.339 and 0.310 , respectively. The predicted El Niño probability was used for scenarios FNiño1 to FNiño5, which simulate the composite effects from the higher frequency along with the strong production effect specified in scenarios SNiño1 to SNiño5 for the El Niño phase. Similarly, scenarios FNiña1 to FNiña3 integrate the higher La Niña frequency with the 3 strong production effects in scenarios SNiña1 to SNiña3 for the La Niña phase.

$5 \& 6$. Trade and Store: To demonstrate the effects of policy response, the scenario Trade simulates the composite effects of scenarios FNiño1 to FNiño5, with a $50 \%$ reduction in rice import tariffs for all rice-trading countries. This scenario attempts to show how trade policy instruments can be used to mitigate the negative effects from strong and more frequent El Niño phenomena. The scenario Store simulates the composite effects of scenarios FNiño1 to FNiño3, with a $50 \%$ storage capacity increase for all rice-trading countries. In contrast to the scenario Trade, the scenario store can provide the rice storage policy outcomes of a domestic mitigation strategy that are useful for decision-making purposes.

\section{SIMULATION RESULTS}

Four sets of empirical results are given in this section. The first setis simulated based on the current ENSO probability distribution (i.e. average scenario) while the second set is simulated based on the extreme El Niño/La Niña events. The third set is simulated on the ENSO probability (i.e. frequency) shifting with the strong El Niño/La Niña events, and the final set is a simulation for the effect of the possible mitigation strategies. The empirical results of economic impacts include trade amount, price, and welfare for all of the trading regions. The major economic outcomes of model solutions for each scenario will focus on trade, prices, and welfare.

\subsection{The effects of an average ENSO}

Table 6 describes the economic effects on trade, prices, and welfare resulting from the occurrence of an average El Niño and an average La Niña event (i.e. scenarios AvNiño and AvNiña). In Table 6, the total amount of rice traded under the El Niño phase increases slightly from 32.6 to 33.0 million metric tonnes, while the La Niña phase does not have much effect on the overall trade volume. However, the individual impact of the ENSO on production and trade is far more profound across trading regions. For instance, the El Niño phase increases rice production in India, 
Table 6. Effects of average ENSO events on trade, prices and welfare by region. Values in parentheses are changes from the Base scenario. AvNiño: average El Niño; AvNiña: average La Niña

\begin{tabular}{|c|c|c|c|c|c|c|c|c|c|}
\hline & \multicolumn{3}{|c|}{ Trade $(1000 \mathrm{t})$} & \multicolumn{3}{|c|}{ Price $\left(\mathrm{US} \$ \mathrm{t}^{-1}\right)$} & \multicolumn{3}{|c|}{ Welfare (US\$ million) } \\
\hline & Base & AvNiño & AvNiña & Base & AvNiño & AvNiña & Base & AvNiño & AvNiña \\
\hline \multicolumn{10}{|l|}{ Exporters } \\
\hline China & 34 & 34 & 34 & 168 & 170 & 176 & 174068 & 174049 & 173971 \\
\hline India & 16772 & 17052 & 16121 & 158 & 159 & 165 & 51307 & 51281 & 51149 \\
\hline Myanmar & 1 & 1 & 1 & 3513 & 3642 & 3925 & 239329 & 238824 & 237734 \\
\hline Pakistan & 1687 & 1739 & 1802 & 245 & 247 & 253 & 8331 & 8332 & 8331 \\
\hline Thailand & 4917 & 5152 & 4780 & 337 & 339 & 345 & 18583 & 18579 & 18565 \\
\hline Vietnam & 5316 & 5199 & 5516 & 1489 & 1491 & 1497 & 147170 & 147108 & 147244 \\
\hline USA & 2821 & 2734 & 3017 & 634 & 635 & 642 & 2887 & 2887 & 2879 \\
\hline South America & 719 & 772 & 885 & 350 & 352 & 358 & 8562 & 8560 & 8549 \\
\hline Australia & 367 & 346 & 374 & 243 & 245 & 251 & 615 & 615 & 613 \\
\hline \multicolumn{10}{|l|}{ Importers } \\
\hline Bangladesh & 4504 & 4268 & 4655 & 331 & 332 & 338 & 115137 & 115152 & 115112 \\
\hline Indonesia & 12499 & 12874 & 12508 & 324 & 326 & 332 & 106511 & 106454 & 106418 \\
\hline Philippines & 3829 & 4060 & 4025 & 440 & 442 & 448 & 32012 & 31966 & 31959 \\
\hline Other Asian & 2951 & 3080 & 2613 & 482 & 484 & 490 & 35131 & 35077 & 35212 \\
\hline Central America & 1669 & 1684 & 1708 & 674 & 675 & 681 & 8095 & 8086 & 8065 \\
\hline Europe & 511 & 512 & 520 & 1357 & 1358 & 1365 & 5214 & 5213 & 5203 \\
\hline Former USSR & 458 & 429 & 452 & 238 & 240 & 246 & 1489 & 1490 & 1485 \\
\hline Brazil & 13 & 13 & 49 & 377 & 376 & 417 & 10145 & 10150 & 10018 \\
\hline Africa & 5835 & 5669 & 5498 & 416 & 418 & 424 & 44962 & 44984 & 44983 \\
\hline Rest of world & 97 & 97 & 97 & 432 & 434 & 440 & 195 & 195 & 195 \\
\hline Total & 32636 & $\begin{array}{r}33030 \\
\quad(394)\end{array}$ & $\begin{array}{r}32533 \\
(-103)\end{array}$ & & & & 1009743 & $\begin{array}{r}1009002 \\
(-741)\end{array}$ & $\begin{array}{r}1007685 \\
(-2058)\end{array}$ \\
\hline \multicolumn{4}{|c|}{ Average export price } & 251.24 & 251.15 & 263.61 & & & \\
\hline \multicolumn{4}{|c|}{ Average import price } & 403.68 & 405.25 & 410.43 & & & \\
\hline
\end{tabular}

but production is reduced during the La Niña phase. Therefore, India exports more rice in El Niño years, and decreases its exports during La Niña years. However, both the El Niño and La Niña phases have negative effects on rice production in the Philippines (Table 3), and as a result, this country increases its imports of rice during these 2 ENSO phases (Table 6).

The domestic supply for trading regions differs according to the ENSO phases, and this causes variations in trade prices. Whether price levels increase or decrease depends on the effects of ENSO on rice production. We find that rice production in most trading regions decreases during an El Niño phase, and therefore prices increase under El Niño (Table 6).

The welfare implications are also calculated in Table 6 . We find that annual total welfare in the international rice market is reduced by US\$741 and US\$2058 million during El Niño and La Niña years, respectively, as shown in the last 3 columns in Table 6 (relative to the Base).

\subsection{Effects of extreme ENSOs}

The effects of the extreme El Niño and La Niña events (i.e. scenarios SNiño1 to SNiño5 and scenarios SNiña1 to SNiña3) on trade, prices, and welfare are averaged separately and summarized in Table 7 . The trade effects of each event on the top 3 trading countries are shown in Fig. 1. Extreme El Niño and La Niña events have a varying effect on the total amount of rice traded in the world, as well as the amount traded in individual countries, during the event. For instance, the model simulations show that the extreme 1965/ 1966, 1982/1983, and 1997/1998 El Niño events and the extreme 1975/1976 and 1988/1989 La Niña events are likely to have opposite effects on the exports of the 2 major rice exporters, India and Thailand. The reason is the differing effects of the extreme ENSO on their domestic rice production differ. So the effect of the strong El Niño and La Niña events on total trade is negative, while the effects on the average export prices are positive (Table 7 ).

Table 7 also shows that additional welfare losses of US\$595 to US\$637 million are likely to occur in the international rice market during extreme ENSO phases. The losses are greater in the extreme La Niña phase, because higher trading volume limitation triggers a higher price in the world market during such an event.

\subsection{Effects of extreme and more frequent ENSOs}

Since ENSO frequency and strength may be altered by climate change, the effects of more frequent ex- 
Table 7. Economic impacts of extreme ENSO events on international rice markets. Values in parentheses are changes from the Base scenario

\begin{tabular}{|lcccc|}
\hline Scenario & $\begin{array}{c}\text { Total amount traded } \\
(1000 \mathrm{t})\end{array}$ & $\begin{array}{c}\text { Average export price } \\
\left(\text { US\$ } \mathrm{t}^{-1}\right)\end{array}$ & $\begin{array}{c}\text { Average import price } \\
\left(\text { US\$ t }^{-1}\right)\end{array}$ & $\begin{array}{c}\text { Total social welfare } \\
\text { (US\$ million) }\end{array}$ \\
\hline Base & 32636 & 251.24 & 403.68 & 1009743 \\
SNiño1(1965/1966 El Niño) & 31666 & 271.38 & 414.12 & 1008636 \\
SNiño2(1972/1973 El Niño) & 32838 & 250.33 & 402.53 & 1009184 \\
SNiño3(1977/1978 El Niño) & 32654 & 257.61 & 407.74 & 1008613 \\
SNiño4(1982/1983 El Niño) & 31505 & 259.46 & 410.33 & 1010732 \\
SNiño5(1997/1998 El Niño) & 32059 & 270.71 & 416.04 & 1008576 \\
Average of SNiño1 to SNiño5 & 32144 & 261.89 & 410.15 & 1009148 \\
& $(-492)$ & $(+10.65)$ & $(+6.47)$ & $(-595)$ \\
SNiña1(1973/1974 La Niña) & 32020 & 265.62 & 412.37 & 1008508 \\
SNiña2(1975/1976 La Niña) & 32236 & 268.20 & 413.74 & 1008501 \\
SNiña3(1988/1989 La Niña) & 33031 & 239.48 & 496.06 & 1010309 \\
Average of SNiña1 to SNiña3 & 32429 & 257.76 & $(+3.71)$ & 1009106 \\
& $(-207)$ & $(+6.52)$ & $(-637)$ \\
\hline
\end{tabular}

treme strong El Niño and La Niña events are examined here. The average economic effects on total world trade, rice exports, and welfare are listed in the second to fifth columns of Table 8 . Such estimation results indicate that total trade volumes are not affected
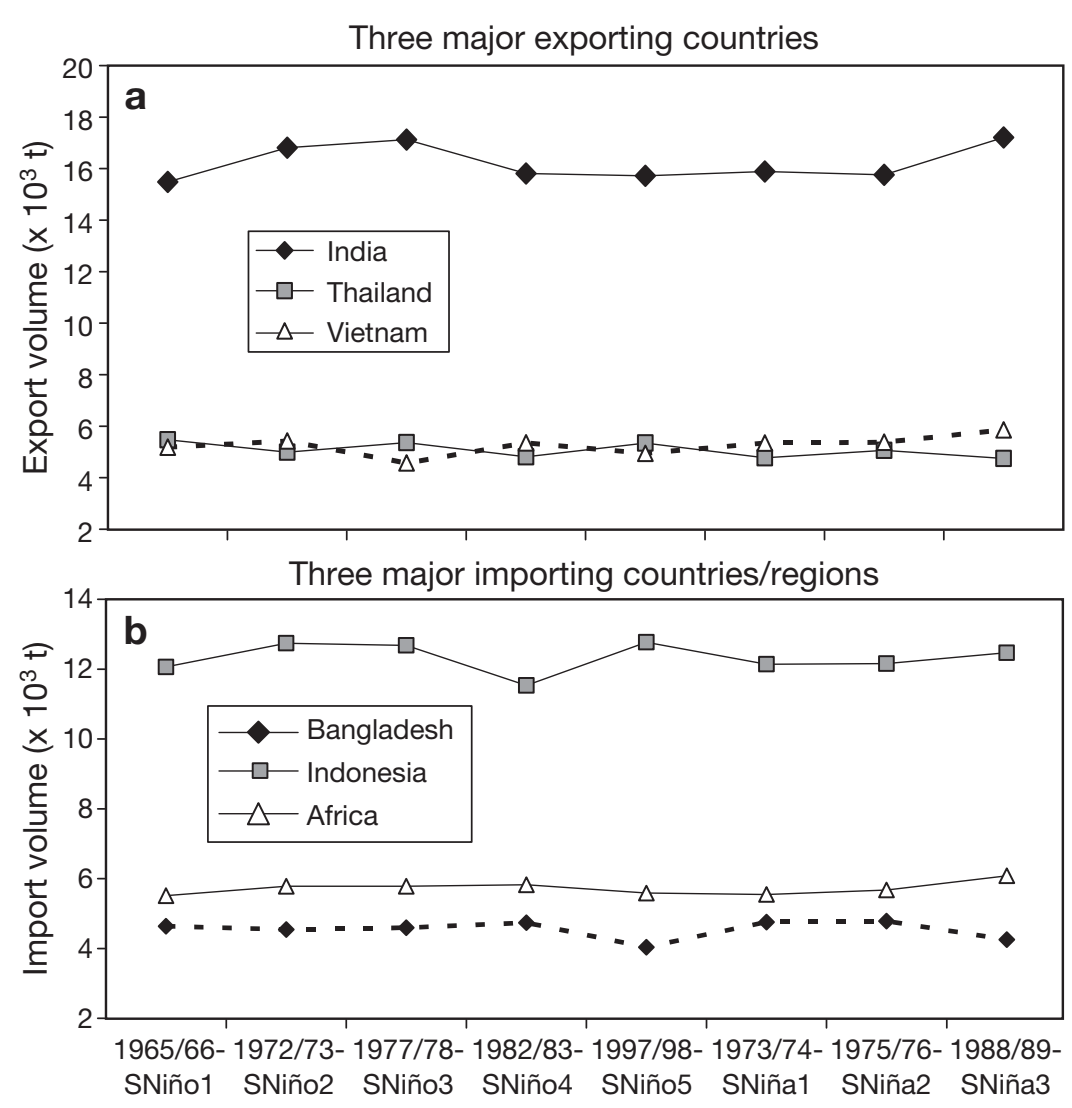

Fig. 1. Effect of extreme ENSO on export and import volumes in major rice trading countries. Due to space limitations, only the trade effect of the top 3 trading countries are shown. The complete results of each extreme event are available upon request exceedingly by the more frequent occurrences of extreme events, but changes in the trade prices are more volatile. Welfare losses might be doubled, as rice exports are interrupted more frequently by extreme El Niño and La Niña events. The total welfare losses could amount to >US\$1300 million under these 2 scenarios.

\subsection{Effects of trade and storage policy responses}

Adaptation strategies including expanding storage capacity, lowering trade barriers, and crop switching could be adopted to mitigate damage to the international rice markets from extreme ENSOs. To simulate the effects of these strategies, the import tariff in each trading country is reduced by $50 \%$ in the scenario Trade, while the storage capacity for each trading country is increased by $50 \%$ in the scenario Store. The economic results are shown in the last 2 rows of Table 8 . We find that both mitigation strategies could be welfare enhancing. However, the Trade strategy, based on a reduction in import tariffs, seems to be slightly more effective than that of a Store strategy, because the former increases the total amount of rice traded significantly. Such an increase in trading activity not only offsets the effects of ENSO, but also increases the total welfare as compared with other scenarios. 
Table 8. Economic effects of extreme and more frequent ENSO events and mitigation policies on international rice markets. Values in parentheses are changes from the Base scenario

\begin{tabular}{|c|c|c|c|c|}
\hline Scenarios & $\begin{array}{l}\text { Total amount traded } \\
\qquad(1000 \mathrm{t})\end{array}$ & $\begin{array}{l}\text { Average export price } \\
\left.\text { (US\$ } \mathrm{t}^{-1}\right)\end{array}$ & $\begin{array}{l}\text { Average import price } \\
\left(\mathrm{US} \$ \mathrm{t}^{-1}\right)\end{array}$ & $\begin{array}{l}\text { Total social welfare } \\
\text { (US\$ million) }\end{array}$ \\
\hline Base & 32636 & 251.24 & 403.68 & 1009743 \\
\hline Average of SNiño1 to SNiño5 & $\begin{array}{r}32144 \\
(-492)\end{array}$ & $\begin{array}{c}261.89 \\
(10.65)\end{array}$ & $\begin{array}{r}410.15 \\
(6.47)\end{array}$ & $\begin{array}{rl}1009 & 148 \\
(-595)\end{array}$ \\
\hline Average of SNiña1 to SNiña3 & $\begin{array}{r}32429 \\
(-207)\end{array}$ & $\begin{array}{r}257.76 \\
(6.52)\end{array}$ & $\begin{array}{r}407.39 \\
(3.71)\end{array}$ & $\begin{array}{r}1009106 \\
(-637)\end{array}$ \\
\hline $\begin{array}{l}\text { Average of FNiño1 to FNiño5 } \\
\text { (strong and more frequent El Niño) }\end{array}$ & $\begin{array}{r}32339 \\
(-297)\end{array}$ & $\begin{array}{c}267.75 \\
(16.51)\end{array}$ & $\begin{array}{l}413.85 \\
(10.17)\end{array}$ & $\begin{array}{rl}1008 & 406 \\
(-1 & 337)\end{array}$ \\
\hline $\begin{array}{l}\text { Average of FNiña1 to FNiña3 } \\
\text { (strong and more frequent La Niña) }\end{array}$ & $\begin{array}{r}32427 \\
(-209)\end{array}$ & $\begin{array}{c}262.43 \\
(11.19)\end{array}$ & $\begin{array}{c}410.3 \\
(6.62)\end{array}$ & $\begin{array}{r}1008351 \\
(-1392)\end{array}$ \\
\hline Trade (tariff reduced) & $\begin{array}{l}41280 \\
(8644)\end{array}$ & $\begin{array}{c}324.91 \\
(73.67)\end{array}$ & $\begin{array}{c}356.17 \\
(-47.51)\end{array}$ & $\begin{array}{r}1011383 \\
\quad(1640)\end{array}$ \\
\hline Store (storage increased) & $\begin{array}{r}31881 \\
(-755)\end{array}$ & $\begin{array}{c}245.39 \\
(-5.85)\end{array}$ & $\begin{array}{c}393.73 \\
(-9.95)\end{array}$ & $\begin{array}{rl}1011 & 121 \\
(1 & 378)\end{array}$ \\
\hline
\end{tabular}

\section{CONCLUSIONS}

The main purpose of this study was to investigate the economic effeccts of extreme El Niño and La Niña events on international rice markets, as well as to estimate the economic effects of more frequent extreme ENSO occurrences. In order to do this, the impacts of average and extreme ENSO events on rice production in major rice-producing countries are estimated using regression analysis utilizing time-series data. We find that there are negative effects on rice production in many major rice-producing countries during strong El Niño and La Niña years.

By using a stochastic spatial equilibrium model, 3 major empirical findings arise. First, rice production decreases and trade volume fluctuates in average ENSO years, resulting in welfare losses up to US\$2800 million on an annual basis. Second, the extreme El Niño and La Niña events could lead to an additional US\$500 to US\$600 million welfare loss, as trade volume is also negatively affected. More frequent extreme ENSO event occurrences as projected by Timmermann et al. (1999) under global warming could raise the economic damages to US\$1.300 million losses in welfare terms. Third, the aforementioned ENSO damages could be partially offset by government mitigation efforts to smooth out the market price fluctuations by lowering tariffs or raising storage capacities.

The simulation results provide 2 policy implications. The first is that the strong 1997/1998 El Niño event resulted in a significant decrease in rice production in India, Vietnam, Indonesia, and the Philippines, which are all less developed economies. Rice is their major staple food, and any instability in production may result in a food security crisis. Therefore, how to miti- gate such a negative impact is a serious policy issue in these countries.

The second policy issue is the efficiency of alternative mitigation options. Two adaptation strategies, including the reduction of import tariffs and an increase in storage capacity are evaluated in this study. We find that the strategy of reducing import tariffs is more effective than that of increasing storage capacity. Rice is a staple food for nearly half of the world's population and is traded internationally. However, only a small proportion of total production is traded, with consumption and production being almost in balance. The reason why there is such a thin international rice market is due to the protectionist policies of the ricetrading countries. However, the new Doha round of negotiations under the auspices of the World Trade Organization (WTO) has asked rice-trading countries to open up their markets through a reduction in import tariffs or an expansion of quotas. Our results suggest that a move in the direction of free trade could be a very effective measure to mitigate the damage caused by the ENSOs.

Nevertheless, there are some assumptions and limitations associated with the simulation model. First, the probability projections of ENSO frequencies are based on the Timmermann et al. (1999) estimation based on the IPCC's earlier projections of greenhouse gas concentration levels. The second limitation is that due to the partial equilibrium nature of the trade model, the economic participants in the model are countries but not necessarily representative of firms or consumers. The linkage effects on the upstream (e.g. seeds, fertilizer) and downstream sectors (e.g. milling, marketing) are also ignored. Therefore, caution should be taken in addressing the policy issues. 
Acknowlegements. C. C. Chen and C. C. Chang were partially funded by the National Science Council and Council of Agriculture, Taiwan.

\section{LITERATURE CITED}

Adams RM, Bryant KJ, McCarl B, Legler DM, O'Brien JJ, Solow AR, Weiher R (1995) Value of improved long-range weather information. Contemp Econ Policy 13:10-19

Centeno HG, Dawe D, Sheehy J, Hammer G (2000) Impacts of ENSO on rice yields in Asia. International Research Institute for Climate Prediction, University of Columbia Lamont, New York

Chen CC, McCarl BA (2000) The value of ENSO information to agriculture: consideration of event strength and trade. J Agric Resour Econ 25:368-385

Chen CC, McCarl BA, Adams RM (2001) Economic effects of shifts in ENSO event frequency and strength. Clim Change 49:147-159

Chen CC, McCarl BA, Hill H (2002) Agricultural value of ENSO information under alternative phase definitions. Clim Change 54:305-325

Cramer GL, Wailes EJ, Shui S (1993) Impacts of liberalizing trade in the world rice market. Am J Agric Econ 75:219-226

Lambert DK, McCarl BA (1989) Sequential modeling of white wheat marketing strategies. North Central J Agric Econ 11:105-115

Mathews RB, Kropff MJ, Horie T, Bachelet D (1995) Simulating the impact of climate change on rice production in Asia and evaluating options for adaptation. Agric Syst 54: $399-425$

Editorial responsibility: Daniel Scott, Waterloo, Ontario, Canada
McDougall R, Elbehri A, Truong TP (1998) Global trade, assistance and protection: the GTAP 4 Data Base. Center for Global Trade Analysis, Purdue University, Lafayette, IN

Mjelde JW, Penson JB, Nixon CJ (1997) Dynamic aspects of the impact of the use of improved climate forecasts in the corn belt region. Final Report NA56GP0266, NOAA, Washington, DC

Redmond K (2007) Classification of El Niño and La Niña winters. Western Regional Climate Center, Reno, NV

Samuelson PA (1952) Spatial price equilibrium and linear programming. Am Econ Rev 42:283-303

Selvaraju R (2003) Impact of El Niño-Southern Oscillation on Indian foodgrain production. Int J Climatol 23:187-206

Solow AR, Adams RM, Bryant KJ, Legler DM and others (1998) The value of improved ENSO prediction to U.S. agriculture. Clim Change 39:47-60

Song JH, Carter CA (1996) Rice trade liberalization and implications for U.S. policy. Am J Agric Econ 78:891-905

Takayama T, Judge GG (1971) Spatial and temporal price and allocation models. North Holland Publishing, Amsterdam

Timmermann A, Latif M, Bacher A, Oberhuber J, Roeckner E (1999) Increased El Niño frequency in a climate model forced by future greenhouse warming. Nature 398: 694-696

Trenberth KE, Hoar TJ (1996) The 1990-1995 El Niño-Southern Oscillation Event: longest on record. Geophys Res Lett 23:57-60

Trenberth KE, Hoar TJ (1997) El Niño and climate change. Geophys Res Lett 24:3057-3060

Zubair L (2002) El Niño-Southern Oscillation influences on rice production in Sri Lanka. Int J Climatol 22:249-260

Submitted: July 5, 2006; Accepted: January 31, 2008

Proofs received from author(s): April 15, 2008 